\title{
15. VERZEICHNIS DER ABGEKÜRZT ZITIERTEN LITERATUR
}

Abh. Sächs. Akad. Wiss., philol.-hist. Kl. AföG

BöW

Boh.

Diefenbach

Diefenbach, Wörterbuch

DS Österr. Akad. Wiss., phil.-hist. Kl.

DuCANGE

FlajšHans, Jazyk

Grinim

ISTC

$J K h S W$

JUNGMANN

KEJR

Klaret

Marcus

MENČIK

$M I \ddot{O G}$
Abhandlungen der Sächsischen Akademie der Wissenschaften, philologisch-historische Klasse.

Archiv für österreichische Geschichte.

Wörterbuch der bairischen Mundarten in Österreich. Hrsg. vom Institut für österreichische Dialekt- und Namenlexika (Bayerisch-österreichisches Wörterbuch I. Österreich). Wien 1963 ff.

Bohemarius, s. Klaret.

Lorenz Diefenbach, Glossarium Latino-Germanicum mediae et infimae aetatis e codicis manuscriptis et impressis. Frankfurt/M. 1857.

Lorenz Diefenbach, Mittellateinisch-hochdeutsch-böhmisches Wörterbuch, nach einer Handschrift vom Jahre 1470. Frankfurt/ M. 1846.

Denkschriften der Österreichischen Akademie der Wissenschaften, philosophisch-historische Klasse.

Charles Ducange, Glossarium mediae et infimae Latinitatis. (Paris) $1883 / 87$. Bd. I-X.

Václav FlajšHans, Nás jazyk matěrsky. Dejíny jazyka českého a vývoj spisovné slovenštiny. Prag 1924.

Jakob und Wilhelm Grinn, Deutsches Wörterbuch I-XVI. Leipzig 1854-1954.

Incunabula Short-Title Catalogue (Database). London $1980 \mathrm{ff}$. Jahrbuch der kunsthistorischen Sammlungen in Wien.

Josef Jungmann, Slownjk česko-némecký I-V. Prag 1835/39.

Jiři KeJR, Die Anfänge der Stadtverfassung und des Stadtrechts in den Böhmischen Ländern, in: Die deutsche Ostsiedlung des Mittelalters als Problem der europäischen Geschichte. Reichenau-Vorträge 1970/72, hrsg. von W. Schlesinger (= Vorträge und Forschungen XVII) Sigmaringen 1975, 439-470.

Václav FlajšHans, Klaret a jeho družina 1-2 (Sbírka pramenů $k$ poznáni literárniho života v Čechách, na Moravě a ve Slezsku 1/1/ Corpus Glossariorum Bohemicorum 1). Prag 1926-1928.

R. P. Marcus, Tu melu besedishe treh jesikov. Das ist : Das kleine Wörterbuch in dreyen Sprachen ... Laibach 1781.

Ferdinand Menčık, Prešpurský slovnik. Vocabularium latinobohemicum Posoniense (Rozmanitosti. Př́spěvky k dějinám starši české literatury 2). Prag 1892.

Mitteilungen des Instituts für österreichische Geschichtsforschung 
SB Österr. Akad. Wiss., phil.-hist. Kl.

StěSl.

SCHMELler

SLovNík středověké

Sudetendt. Wb.

\section{Veröffentlichungen des IfÖG}

VINTR

WiŽ̌̌ÁLKová

WUSSIN
Sitzungsberichte der Österreichischen Akademie der Wissenschaften, philosophisch-historische Klasse.

Staročeský slovník. Prag 1977 ff.

Josef Andreas Schmelter, Bayerisches Wörterbuch. 2. Aufl. bearb. von G. Karl Frommann 1-2. München 1872-77.

SLovNík středověké latiný v českých zemích. Latinitatis medii aevi Lexicon Bohemorum. ... Československá Akademie vĕd. Prag 1977 ff.

Sudetendeutsches Wörterbuch. Wörterbuch der deutschen Mundarten in Böhmen und Mähren-Schlesien. Hrsg. von Heinz Engels und Otfrid Ehrismann. München $1988 \mathrm{ff}$.

Veröffentlichungen des Instituts für österreichische Geschichtsforschung.

Josef VINTR, Das Tschechische. Hauptzüge seiner Sprachstruktur in Gegenwart und Geschichte (Slavistische Beiträge $403=$ Studienhilfen 11). München 2001.

Bedřiška Wiž̄̌ÁLKová, Nejstarší známý tištěný vokabulář. Miscelanea odděleni rukopisů a vzácných tisků 1 (1971) II, 1-160.

Caspar Zacharias Wussin, Lexicon tripartitum oder TeutschLateinisch und Böhmisches Wörter-Buch.... Dritte Auflage. Prag 1742 . 